
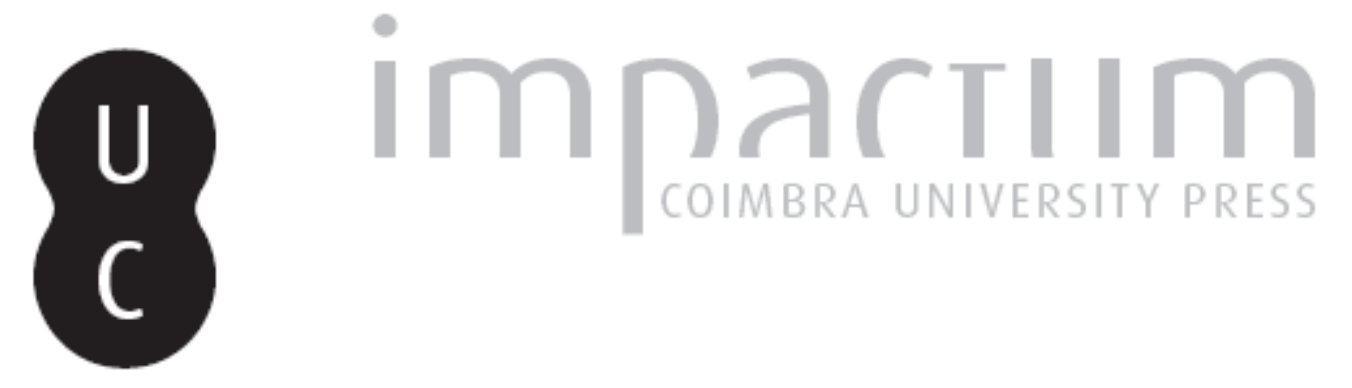

A carta de D. Manuel ao Papa Leão X (1513)

Autor(es): $\quad$ Soares, Naïr de Nazaré Castro

Publicado por: Faculdade de Letras da Universidade de Coimbra

URL persistente:

URI:http://hdl.handle.net/10316.2/39969

DOI:

DOI:https://doi.org/10.14195/0870-4112_2_3

Accessed : $\quad$ 26-Apr-2023 13:12:31

A navegação consulta e descarregamento dos títulos inseridos nas Bibliotecas Digitais UC Digitalis, UC Pombalina e UC Impactum, pressupõem a aceitação plena e sem reservas dos Termos e Condições de Uso destas Bibliotecas Digitais, disponíveis em https://digitalis.uc.pt/pt-pt/termos.

Conforme exposto nos referidos Termos e Condições de Uso, o descarregamento de títulos de acesso restrito requer uma licença válida de autorização devendo o utilizador aceder ao(s) documento(s) a partir de um endereço de IP da instituição detentora da supramencionada licença.

Ao utilizador é apenas permitido o descarregamento para uso pessoal, pelo que o emprego do(s) título(s) descarregado(s) para outro fim, designadamente comercial, carece de autorização do respetivo autor ou editor da obra.

Na medida em que todas as obras da UC Digitalis se encontram protegidas pelo Código do Direito de Autor e Direitos Conexos e demais legislação aplicável, toda a cópia, parcial ou total, deste documento, nos casos em que é legalmente admitida, deverá conter ou fazer-se acompanhar por este aviso. 
REVISTA DA FACULDADE DE LETRAS U N I VERS I A D E D E C O I M B RA 
Universidade de Coimbra

\title{
A Carta de D. Manuel ao Papa Leão X (1513)
}

\author{
«E, sujeita a rica Áurea Quersoneso, \\ Até o longinco China navegando \\ $E$ as ilhas mais remotas do Oriente, \\ Ser-lhe-á todo o Oceano obediente».
}

Camões, Os Lusíadas, II, 54

Abstract:

D. Manuel's letter to Pope Leon $X$ (1513) about the victories he achieved in India and Malaca narrates, according to the stilus epistularum, with an almost journalistic sensationalism, the heroic exploits that constitute the main theme of this elegant obedience oration pronounced by Diogo Pacheco in Tristão da Cunha's embassy, the following year (1514) - the most famous of all for its splendor and for the exoticism of the elephant offered to the Pope.

The letter, aiming at international propaganda, centered on the laudatio principis as imperator and rex inuictissimus, and is the most complete expression of the rhetoric of power and of epic glorification in the golden period of our History of overseas expansion.

Os sucessos dos Portugueses nas paragens de Além-mar aca lentaram a sensibilidade colectiva nacional e deixaram, pela sua univer salidade, marcas indeléveis, na literatura e na cultura do Renascimento.

$\mathrm{O}$ ideal de enaltecimento pátrio da «pequena casa lusitana» que acompanhou a empresa dos Descobrimentos, a expansão da Fé e do Império - afirma-se desde cedo na nossa literatura, em latim e em vernáculo.

Já na crónica sobre a tomada de Ceuta, o De Septensi bello, o primeiro texto que divulga em latim a gesta portuguesa, Mateus de Pisano faz a descrição dos feitos "tamanhos que a custo os haverá por verdadei ros quem pretenda aferir-lhes a grandeza pelos recursos de que dispõe tal 


\section{Nair de Nazaré Castro Soares}

povo"1. A mesma ideia surge na oração proferida pelo Conde de Alcoutim, D. Pedro de Meneses, a 18 de Outubro de 1504, na abertura solene das aulas na Universidade; e em carta dirigida por Cataldo ao rei

D. Manuel, onde transparece o universo épico que Camões traduziu em plenitude ${ }^{2}$.

Do ponto de vista semântico-conceptual, o louvor das glórias lusas tem por referência, quase constante, os feitos de gregos e romanos. Esta evocação da alteridade pelo processo da inversão funciona como princípio heurístico e concorre para a elaboração de uma representação do mundo: os portugueses são superiores aos antigos pela sua missão evan gelizadora, pela propagação da fé, que os anima ${ }^{3}$.

Os sucessos lusos, naquilo que de grandioso e de exotismo encerravam, marcam toda uma geração de portugueses e mesmo de estrangeiros, a quem as notícias chegavam, a partir de Roma, e pelo con tacto directo com os nautas, em Lisboa ou na Flandres, ligadas por uma carreira regular de naus, duas vezes por ano, desde $1502^{4}$.

Assim acontece com Thomas More que se deixara impressio nar com a leitura do livro de Vespuccio, e que admirara, como homem da sua época, a empresa marítima e os marinheiros lusos que o teriam inspi rado na criação de Raphael Hithodeu, português, o herói da sua obra de alcance universal, a Utopia, publicada em Londres em $1516 .{ }^{5}$

Em Roma, desde os finais do Quattrocento, eram habituais as celebrações, por parte da cúria romana, dos feitos dos portugueses, que ganhavam universalidade pela luta contra os Turcos, um serviço prestado à cristandade, que as orações de obediência enalteciam acima de tudo.

1 Cf. a tradução por Roberto Corrêa Pinto, publicada pela Academia das Ciências de Lisboa, em edição da Imprensa da Universidade (Coimbra 1915).

2 Vide, para estas obras e sua análise, os estudos de Américo da Costa Ramalho, Estudos sobre o século XVI (Paris 1980); Estudos Camonianos (Lisboa 2 1980); Epistolae et orationes de Cataldo Parísio Sículo, edição fac-similada com introdução, (Coimbra 1988).

3 Vide Nair de Nazaré Castro Soares, "A História Antiga no Humanismo Renascentista Português", in Actas do II Congresso Peninsular de História Antiga. (Coimbra, 18-20 Out. 1990) (Coimbra 1994) 280-305.

4 Refira-se, como exemplo, o caso do florentino Girolamo Sernigi que, mal chegou a Lisboa uma das caravelas da primeira viagem de Vasco da Gama à índia, se apressou a dar a notícia para Itália do sucesso do empreendimento.

3 A obra de Vespuccio, Paesi nuovamente retrouati. Nouo Mondo da A Ibérico Vesputio Florentino intitulato (1507) foi traduzida para latim com o título Itinerarium Portugal le nsium e Lusitania in India et inde in occidentem (1508). 


\section{A Carta de D. Manuel ao Papa Leão X}

Todas as orações proferidas perante o papa, ou as cartas que lhe eram enviadas, a dar notícias das descobertas e conquistas ultramari nas, desde o reinado de D. Afonso $\mathrm{V}$ aos de D. João II e de D. Manuel, retomam sempre o mesmo motivo - a guerra contra os Turcos, a defesa e a expansão da Fé cristã. Os Turcos já não são só os do norte de África, mas os seguidores do Islão, nas paragens distantes do índico e do Mar Vermelho.

Ficaram famosas orações como a de D. Garcia de Meneses, em 1481, perante Sixto $\mathrm{IV}^{6}$, e as duas proferidas por Diogo Pacheco, uma perante Júlio II, na embaixada de D. Diogo de Sousa, em 1505, e outra perante Leão $X$, na de Tristão da Cunha, em 1514. Esta última embaixada foi realizada na continuidade dos feitos heroicos relatados na carta que D. Manuel escreve a Leão X, em $1513^{7}$.

As orações de obediência e as celebrações públicas de júbilo pelos grandiosos feitos lusos, com festas, procissões, missas solenes e pregações, bem como a divulgação pela imprensa romana das cartas da chancelaria portuguesa que davam notícia das conquistas ao infiel, em círculos mais restritos, contribuem para a criação de um mundo de fanta sia, de utopia, que se reflecte no imaginário de escritores e artistas como Egidio da Viterbo, Francesco Albertini, Dürer. ${ }^{8}$

A aura mítica que se criou em torno das façanhas dos portu gueses, nas mais remotas paragens do globo, levou Egidio da Viterbo a afirmar, em 1507, num sermão proferido em Roma nas festividades que

${ }^{6}$ A oração de D. Garcia de Meneses, pronunciada em 1481 perante o papa Sisto IV, figura na Chorografia de Gaspar Barreiros com o seguinte título: Hüa Oraçam que fez dom Garcia de Meneses bispo d'Euora, ao Papa Sixto quarto em Roma na igreja de sanct. Paulo extra muros, onde foi pubricamente recebido, indo por capitam de hüa armada que elrei dom Affonso o quinto de Portugal mandou, em socorro da cidade de Ottranto que os Turcos tinham tomado no regno de Nápoles. Vide a publicação moderna, Oração ao Sumo Pontífice Sisto IV dita por D. Garcia de Meneses em 1481. Edição fac-similada, com nota bibliográfica de Martim de Albuquerque e tradução portuguesa de Miguel Pinto de Meneses, in Orações de obediência, séculos XV a XVII, 10 vols., (Lisboa 1988): vol. 2. Sobre esta oração que foi louvada por Pomponio Leto, no momento em que foi proferida, e que merecia ainda, em meados do século XVI, rasgados elogios do cardeal Jacopo Sadoleto, vide a carta dirigida por Gaspar Barreiros a Jorge Coelho (Évora, 28 de abril de 1553), in Orações de Obediência cit., vol 1.

7 Ibidem, vol 6: “Oração do jurisconsulto Diogo Pacheco, dita na prestação de obediência em nome de Manuel, Invictissimo rei de Portugal, ao excelente Sumo Pontífice Leão $X$.

8 Vide Sylvie Deswarte, "Un âge d' Or. La gloire des Portugais à Rome sous Jules II et Léon X", in Humanismo Português na época dos Descobrimentos (Congresso internacional - Coimbra, 9-12 de Outubro de 1991), Actas (Coimbra 1993) 126-150. 
Júlio II promovera para celebrar as nossas vitórias no Oriente, que nada desejava mais neste mundo do que ser Português. ${ }^{9}$

Neste mesmo ano, o carmelita Giovanni Baptista Mantuano faz o elogio rasgado das viagens marítimas dos portugueses, louva os seus progressos na ciência náutica, o seu papel na expansão e consolidação da Fé. ${ }^{10}$

Jean Delumeau, na sua obra Mil anos de felicidade. Uma histó ria do paraíso, dedica um capítulo inteiro ao milenarismo português, sendo cerca de uma dezena de páginas sobre "o sonho de Manuel, o ven turoso", que projectava uma espécie de império universal e messiânico ${ }^{1} \boldsymbol{K}$

Gil Vicente, no Auto da Fama, escrito em 1510, chama a D. Manuel «alferes da fé /e rei do mar» ${ }^{12}$.

A corte manuelina e a cosmopolita cidade de Lisboa são tam bém o reflexo da grandeza imperial portuguesa. Os autores quinhentistas não se cansam de descrever o esplendor dos paços de D. Manuel — as festas, a música, em que o rei e o jovem Damião de Góis eram aficiona dos, e os serões animados pelo teatro de Gil Vicente.

Lisboa toma-se famosa pela azáfama do seu porto, o exotismo e as riquezas provenientes do mundo novo, as embarcações, as diferentes raças e línguas da mais variada gente, as celebrações das vitórias de alémmar, em especial no Oriente, como a conquista de Malaca, ou o recebi mento de Mateus - o embaixador do Preste João que trazia para D. Manuel um pedaço do lenho da Vera Cruz, recebido do Guardião de Jerusalém.

Este sentimento contagiante de entusiasmo pelas nossas Des cobertas, pelo desconhecido, caldeado com o proselitismo cristão, que crê no estabelecimento de uma respublica Christiana sob a égide de Portugal, aflora no imaginário dos mais diversos autores, nos anos subsequentes à grande aventura marítima do Gama.

Ibidem, 129-131. Sobre o discurso de Egidio da Viterbo e sua importância, pela repercussão que teve nos temas que figuram na abóbada da Capela Sixtina e na Stanza della Segnatura de Rafael, Ibidem, 133 sqq.

19 Sebastião Tavares de Pinho, "Turcos, Árabes e Descobrimentos na voz do Virgílio Cristão: comentário a um poema de Baptista Mantuano", in Actas do Congresso Internacional Bartolomeu Dias e a sua época, vol. IV (Porto 1989) 135-163.

11 Jean Delumeau, Mil anos de felicidade. Uma história do paraíso, trad, port., (Lisboa 1997) (ed. original, Paris 1995), cap. $X$ : “O milenarismo português", 217-236, 491-493 .

12 Obras de Gil Vicente. Direcção científica de José Camões. 2 vols. (Lisboa, Centro de Estudos de Teatro - Imprensa Nacional-Casa da Moeda 2002): fala da Fama em diálogo com o Italiano, vol. II, 194.

Faculdade de Letras i Universidade de Coimbra 
A exaltante atmosfera moral, aliada à consciência da hiperidentidade que caracteriza os homens de Quinhentos, transparece na prosa histórica em vulgar e em latim. Ganha forma a historia monográfica - de humanistas como André de Resende, Diogo de Teive e Damião de Góis -, em que o sensacionalismo tem um lugar de relevo.

$\mathrm{O}$ enaltecimento do rei e seus cometimentos toma-se urna constante na historiografía portuguesa desta época, que era essencial mente nacional e dinástica e atribuía a maior importância aos triunfos militares e à coragem de um povo, nas remotas paragens onde se estendia o império13. Os cronistas e escritores de Quinhentos preocupam-se em salientar o perfil humano, político e religioso do monarca. Avulta a figura do rei legislador, do rei arquitecto da Lisboa monumental, a sua acção governativa, a sua riqueza e monopólio do comércio do Oriente, a sua majestas e magnificentia como Pater patriae de uma nação «quasi cume da cabeça de Europa toda», como diria Camões $\{$ L Lus., III. 20).

Marco na nossa história das ideias e da doutrina política é o tratado De republica gubernanda per regem (1496) de Diogo Lopes Rebelo, dedicado a D. Manuel, por apresentar uma imago principis, deli neada em termos de regalismo romanista. $O$ absolutismo régio deste autor reflecte a evolução política europeia e prenuncia a tendência para a afir mação do poder absoluto dos reis, que encontra eco nas Ordenações Manuelinas - elaboradas entre 1505-1514, ano este da primeira impressão da obra.

Não se pode esquecer que o manuscrito de 11 principe de Maquiavel, onde é usada pele primeira vez a palavra "estado", data de 1514, e abre caminho ao princípio da soberania de estado, formulada, em finais deste século, pelo jurista Jean Bodin.

Apesar disso, firmou-se em Portugal, durante o século XVI, a imagem do príncipe, modelo de todas as virtudes humanas, pastor de povos, sol que a todos alumia, de inspiração clássica, e de acordo com a teorização tomista, actualizada pela lição de Francisco de Vitória* ${ }^{14}$.

A mundividência que transparece na carta de D. Manuel ao Papa Leão X, de 1513, embora assente nestes pressupostos éticos, jurí

$\wedge$ Cf. Nair de Nazaré Castro Soares, 'A historiografia do Renascimento em Portugal: referentes estéticos e ideológicos humanistas', in Aquém e Além da Taprobana. Estudos Luso-Orientais à memória de Jean Aubin e Denys Lombard. Edição organizada por Luís Filipe F. R. Thomaz (Lisboa 2002) 15-37.

D. Jerónimo Osório (Coimbra 1994).

Vide Nair de Nazaré Castro Soares, $O$ príncipe ideal no século XVI e a obra de

Faculdade de Letras i Universidade de Coimbra 
dico-políticos, tem por objectivo a divulgação, a propaganda da gesta portuguesa, na cúria Romana.

Em 1511, deu-se a conquista de Malaca, a “Áurea Quersoneso". Desta façanha do grande Afonso de Albuquerque logo o rei D. Manuel, em carta latina, enviou notícia ao Papa Leão X, que festejou o grande evento. Houve missa de acção de graças, na Basílica de S. Pedro, procissão solene e uma oração, pronunciada pelo poeta e cónego Camillo Porzio, onde se sublinha a importância deste feito heroico e se chama a atenção para o perigo turco ${ }^{15}$.

A Epístola de D. Manuel ao Sumo Pontífice (datada de Lisboa, 6 de Junho de 1513) foi impressa em Roma, nos prelos de lacobus Mazochius - que tantas vezes divulgaram a gesta lusa - com data de 9 de Agosto de 1513, o que é bem expressivo do horizonte de expectativas do público, na época áurea da nossa história ultramarina ${ }^{16}$.

Pouco depois, em 5 de Setembro deste mesmo ano, o sumo Pontífice respondeu a esta carta do nosso rei, manifestando grande alegria pelas vitórias na índia e em Malaca, pela chegada do embaixador de Prestes João e pela próxima partida de Afonso de Albuquerque para o Mar Vermelho, resumindo assim as principais notícias narradas ${ }^{17}$.

As novas do Oriente, trazidas pelas naus que acabavam de aportar em Lisboa e narradas ao Sumo Pontífice, com a maior brevidade

15 Sobre as celebrações pela vitória dos portugueses, vide Comentários de Afonso de Albuquerque (conforme a edição de 1576), com prefácio de J. Veríssimo Serrão (Lisboa 1973) tomo II, p. IIl, cap. XXXIX, 190-206. Deste acontecimento nos dá notícia, no Panegírico da Infanta D. Maria, João de Barros, Panegíricos (Lisboa, Sá da Costa 1943) 169-171.

16 Epistula ac inuictissimi Emanuelis Regis Portugaliae et Algarbiorum, etc. De uictoriis habitis in India et Malacha. Ad Sanctum in Christo Patrem et Dominum nostrum Dominum Leonem $X$, Pontificem Maximum - 'Epístola do muito poderoso e invencível Manuel, rei de Portugal e dos Algarves, etc. Das vitórias que obteve na índia e em Malaca. Ao Santo Padre, em Cristo, e Senhor Nosso, Senhor Leão X, Sumo Pontífice'. Reprodução fac-similada, leitura moderna, tradução e notas de Nair de Nazaré Castro Soares, in Acta Rediviva, II, publicação da Biblioteca Geral da Universidade de Coimbra (Coimbra 1979). Da grande divulgação que esta carta conheceu, no século XVI, vide Luís de Matos, "L'expansion portugaise dans la littérature latine de la Renaissance", in L'Humanisme Portugais et l'Europe - Actes du XXIe. Colloque International d'Etudes Humanistes, Tours, 3-13 juillet 1978 (Paris 1984) 417. Estes mesmos acontecimentos viriam a ser narrados pelo cronista Damião de Góis, na III Parte da sua Crónica do felicíssimo rei D. Manuel, sendo notável a descrição que se encontra no capítulo XVIII sobre a riqueza de Malaca e sua importância como empório comercial.

17 Vide Luiz Augusti Rebello da Silva em Corpo Diplomático portuguez, Academia Real das Sciencias (Lisboa 1862) tomo I, 201-202; Comentários de Afonso de Albuquerque, tomo II, p. Ill, cap. XXXIX, 190-206.

\section{Faculdade de Letras i Universidade de Coimbra}




\section{A Carta de D. Manuel ao Papa Leão X}

possível, são factos históricos relatados pela pena dos nossos escritores quinhentistas, o que realça o interesse desta carta à luz das crónicas do tempo ${ }^{18}$. Todas elas repetem ou desenvolvem os factos veiculados por esta missiva, e que são também tema principal da oração de obediência de Diogo Pacheco, na embaixada de Tristão da Cunha, no ano seguinte, de 1514, a mais famosa de todas pelo exotismo e grandiosidade. Integrou-a, como presente de $\mathrm{D}$. Manuel a Leão $\mathrm{X}$, o célebre elefante, que ficou na memória colectiva da época e consta de todos os relatos ${ }^{19}$.

Esta carta, sem sair do estilo epistolar, ne stilum epistularum excedamus, está construída segundo os princípios da retórica, podendo considerar-se uma carta erudita, que privilegia os géneros deliberativo e epidictico $^{20}$.

Abre-a um exórdio, a que não faltam a captatio beneuolentiae, uma espécie de dedicatória e a apresentação da matéria, onde é nítida a influência de Salústio \{Çat. 3-4). Segue-se o desenvolvimento do tema, a descriptio rerum, a narração dos feitos gloriosos no Oriente, nas seguintes dimensões: enaltece-se o poder militar, a capacidade do exercício da força de um rei, senhor de um imperium - pelo braço armado de Afonso de Albuquerque, em seu nome - ; o alcance religioso e proselítico das con quistas; a sua vertente económica, por ser o comércio e a actividade mer cantil fonte de riqueza nacional; e, a englobar todos estes aspectos, a

18 Diversas são as obras históricas quinhentistas que narram os factos que estão relatados nesta carta (de Junho de 1513), como novidade. Vide os documentos coevos Comentários de Afonso de Albuquerque, tomo II, p. III; Cartas de Afonso de Albuquerque seguidas de documentos que as elucidam, ed. Raimundo António Bulhão Pato, Lisboa, Academia Real de Sciencias, 1884-1915. Cf. ainda e. g. Damião de Góis, Crónica do felicíssimo rei D. Manuel, Coimbra, 1954; Fernão Lopes de Castanheda, História do descobrimento e conquista da Índia pelos Portugueses, por Pedro de Azevedo (Coimbra 1924); D. Jerónimo Osório, Da vida e feitos de El-rei D. Manuel, (trad, port.), (Porto) 2 vols., 1944; João de Barros, Ásia por António Baião e Luís F. Lindley Cintra (Lisboa 41974); Gaspar Correia, Lendas da Índia (Lisboa 1860). Recorre-se a estas obras apenas quando é estritamente necessário para o entendimento do texto (com citação abreviada).

O cotejo da Carta do rei D. Manuel ao papa Leão $X$ com todas estas obras foi feito exaustivamente na minha edição desta carta (vide supra n. 16), pelo que nos dispensamos de o fazer sistematicamente.

19 Vide a descrição circunstanciada, «cinematográfica», das celebrações, em Roma, aquando da recepção da carta de D. Manuel, em 1513, e, por ocasião da embaixada de Tristão da Cunha, no ano seguinte, in: Elaine Sanceau, $O$ reinado do Venturoso (Porto 1970) 157-170.

20 Cf. Erasmo, De conscribendis epistulis, caps 31-32 e 74. Foi a partir da publicação da epistolografia de Cícero, Séneca e de Plínio-o-Jovem que surgiram diversos tratados quinhentistas sobre a arte de escrever cartas, no Renascimento, podendo considerar se o de Erasmo o mais expressivo. 
dimensão épica, como expressão acabada do heroísmo de um povo que serve, com fervor cruzadístico, o seu Deus e, com lealdade, o seu rei ${ }^{21}$. Por fim a peroratio.

O exórdio, o pórtico da epístola, dentro dos princípios retóricos sintetizados por Cícero $^{22}$, Caracteriza-se pelo tom grave e nobre. É esta busca de gravidade e nobreza uma das formas de despertar a atenção para a matéria a tratar, ao mesmo tempo que o autor dá de si uma boa imagem e capta a benevolência do suposto auditório. Assim, ao iniciar a Carta ao Sumo Pontífice, D. Manuel - que fala na primeira pessoa ${ }^{23}$ - é apresentado com todos os seus títulos, enunciativos da extensão do seu império, do seu poder ${ }^{24}$ :

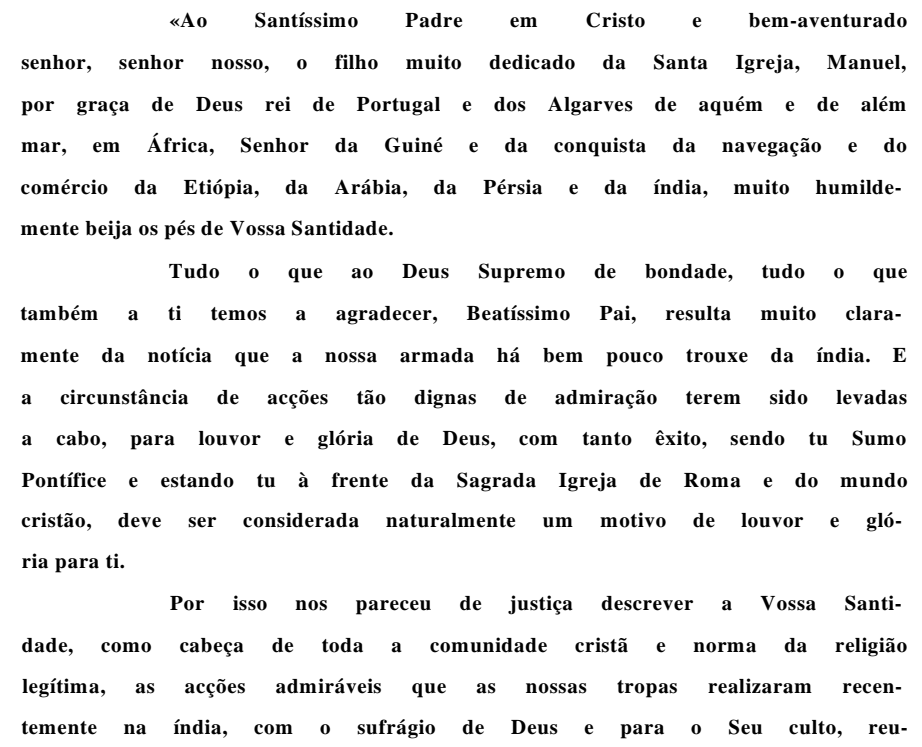

? 1 Vide Nair de Nazaré Castro Soares, 'Gratidão e lealdade: dois valores humanistas', II parte da Miscelânea em honra dos Doutores Walter de Medeiros e Manuel Pulquério - Humanitas 46(1994)245-258.

22 Aristóteles, Cícero, Quintiliano trataram longamente desta matéria: Arist., Rhet., 1414b-1416a; Cic. e. g. Inu., I, 15-18; Rhet. Her., I. 4-7; Quint., Inst., IV, 1-79.

23 Na oração de obediência de 1514, por ocasião da embaixada de Tristão da Cunha, feita por Diogo Pacheco, «em nome de Manuel, Invictissimo rei de Portugal», os títulos do monarca não figuram.

240 texto latino encontra-se apenso a este estudo, em fac-simile da edição de Roma, de Iacobus Mazochius, com data de 9 de Agosto de 1513. A tradução segue este texto e é apresentada na íntegra, interrompida apenas pelos comentários ao texto.

\section{Faculdade de Letras Universidade de Coimbra}




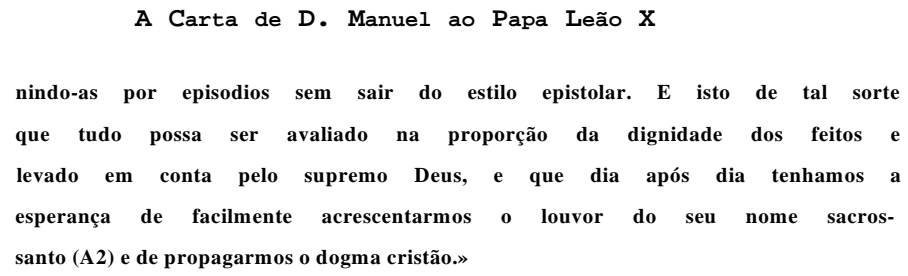

Segue-se a descrição da conquista de Malaca, antecedida do seu elogio. Muitas são as referências que lhe fazem os diversos autores da época, em prosa e em verso.

Interessantes são as palavras de Camilo Pórcio, na Oração pro ferida em Roma, em Outubro de 1513, perante o Papa Leão X, em louvor dos feitos dos Portugueses em Malaca e na índia25:

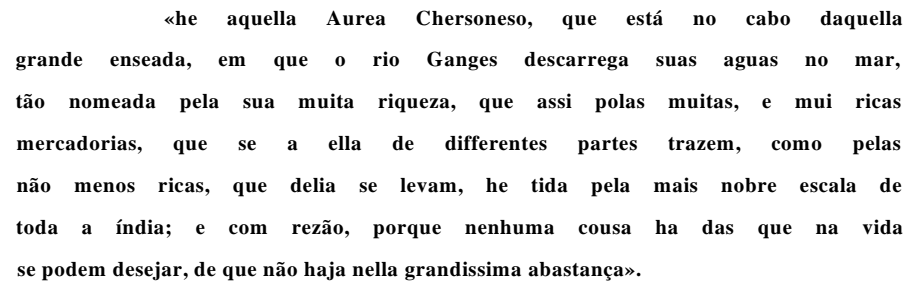

Todas as crónicas do século XVI que se ocupam deste feito de Afonso de Albuquerque referem o sítio da cidade, a sua grande riqueza e como se fez reino, não raras vezes, em termos que primam pela beleza e pitoresco da descrição 2627.

«Louvam-se as cidades do mesmo modo que os homens», afirma Quintiliano, na sua Institutio oratoria (3. 7. 26): decorrido mais de meio século, Góis fará a descrição de Malaca, na Crónica do felicíssimo rei D. Manuel, seguindo os tópicos retóricos próprios do elogio das cida des, que já pusera em prática na Vrbs Olisiponis descriptio ${ }^{11}$.

E, em 1572, Camões cantava-a n’ Os Lusíadas (canto II. 54, vV.5-8).

25 Esta carta foi transcrita em Comentários de Afonso de Albuquerque, tomo II, p. Ill, cap. XXXIX, 190-206: "Oração, que Camillo Porcio fez ao Papa Leão Decimo em louvor da tomada de Malaca: e das vitorias, que os Portugueses tiveram da conquista da India."

${ }^{26}$ Vide e. g. Castanheda, liv. II, cap. CXII; Jerónimo Osório, vol. I, liv. IV, 312.

27 Vide Góis, p. Ill, cap. I, p. 3. É notável a descrição que se encontra no capítulo XVIII.Cf. Supra, n. 16. 
A epístola continua:

«É que Afonso de Albuquerque, nosso Capitão-Mor depois de muitas vitórias do incerto Marte, conseguidas não sem trabalho e sangue $^{*}{ }^{2 * *}$, pacificou a índia, deixou nela as guarnições necessárias ${ }^{2 \wedge} \mathbf{e}$, para vingar o dano e a injúria que nos causaram em anos anteriores ${ }^{2 \wedge}$ atacou a aurea Quersoneso, que os vizinhos chamam Malaca ${ }^{21}$. Fica situada entre 0 grande golfo e 0 do Ganges e é uma cidade de admirável grandeza, avaliada em mais de vinte e cinco mil lares. A terra em si é muito fecunda e riquíssima naquelas mercadorias mais conhecidas que a índia produz. Por isso mesmo é empório muito célebre, onde afluem não só variadas especiarias e perfumes de todo 0 género, mas ainda grande quantidade de ouro, prata, pérolas e pedras preciosas.

Depois de referir a situação e riqueza da cidade, empório mer cantil, a carta continua a sua caracterização, apresentando a sua identi dade, as crenças e religião das suas gentes: «Govemava-a um rei mouro, estendendo até aí o seu poder a seita maometana».

A identificação da seita de Maomé, que, no Oriente, se opunha à evangelização cristã - como na Europa ameaçava a unidade religiosa -, torna-se, do ponto de vista conceptual, causa primeira de guerra justa. Implicitamente, o enunciador do discurso sugere esta interpretação. Os motivos de ordem material são coroados por uma razão superior, sobre natural, pelo que o alargamento do poder militar e político-administrativo do Império pelo braço do «Leão dos mares» correspondia à missão evan gelizadora e proselítica que o animava.

${ }^{\mathrm{T} 0}$ Vide Comentários de Afonso de Albuquerque, tomo II, p. III, cap. III, 11.

${ }^{y}$ vide Comentários de Afonso de Albuquerque, tomo II, p. III, cap. Ix, 51-52; Góis, p. IIl, cap. XVII, 72.

2^ Há aqui uma referência à traição que o rei de Malaca, Mohamede, e o seu Bendará cometeram contra Diogo Lopes Sequeira e sua armada, tendo morrido muitos e outros ficado feridos. Apesar do que tinha sucedido, ao aportar a Malaca, Afonso de Albuquerque não ataca a cidade, mas recebe as justificações mentirosas do rei, exigindo, no entanto, que antes de mais «lhe havia de mandar Rui daraujo, \& hos Christãos que allí ficaram, com toda a fazenda» (Damião de Góis, p. Ill, cap. XVIII, p. 76). O rei, não cumprindo com o combinado, entretinha os portugueses até que lhe viesse maior auxílio. As falsas intenções de Mohamede foram percebidas por Afonso de Albuquerque que ataca a cidade e a toma pela força. De grande interesse é o relato que, a este propósito, Albuquerque envia ao rei de sião \{Comentários de Afonso de Albuquerque, tomo II, p. III, cap. Xxxví, 176-177).

21 João de Barros (Asia, Segunda Década, liv. VI, cap. I, p. 247-248) explica o motivo por que se dá a Malaca o nome de Aurea Chersoneso. Camões exprime de forma poética a mesma ideia (Cte Lusíadas, $\mathbf{x}, \mathbf{1 2 4})$. 
Narra-se 0 combate travado com 0 rei mouro, a vitória dos Portugueses e a recolha dos valiosos despojos. 0 realismo da descrição bélica, à semelhança de muitas outras que figuram nos Comentários de Afonso de Albuquerque, revela bem a distância a que se encontra este texto, de carácter propagandístico, dos escritos historicos de humanistas, como Góis ou Teive - que fizeram a narração do "Segundo cerco de Diu" "32. A ambos subjaz uma preocupação grande de verdade histórica, traduzida na valorização do inimigo e na racionalidade na interpretação dos factos.

No entanto, a insistência em pormenores que traduzem a superioridade dos portugueses sobre os Sarracenos merecem-nos uma reflexão que se prende com a mensagem que $D$. Manuel quer transmitir ao seu leitor privilegiado, o Papa Leão X, e, na sua pessoa, urbi et orbi: Ela é a expressão da potentia, 0 poder militar da nação lusa, necessariamente apoiado numa bem fornecida máquina de guerra, que assegura o domínio militar e comercial, nas paragens longínquas do Sol Nascente. A potentia une-se a nobilitas, as duas redeas que segura 0 governante ideal, na condução dos destinos colectivos — como as representa Dürer, no desenho preparatório do carro triunfal de Maximiliano ${ }^{33} \leftarrow$ - porquanto se põe 0 acento na pietas, na dilatação da Fé, no aumento e consolidação da respublica Christiana.

\section{Assim prossegue a carta:}

«Governava-a um rei mouro $0^{34}$, estendendo até aí o seu poder a seita maometana. 0 resto é ocupado pelos gentios ${ }^{33}$. E assim,

32 0s feitos dos portugueses, no cerco de Diu de 1546, são exaltados por Diogo de Teive, no opúsculo Commentarus de rebus in India apud Dium gestis anno salutis nostrae MDXLVI e por Damião de Góis, no De bello Cambaico Vitimo commentarii tres. Vide Nair de Nazaré Castro Soares, Tragédia do Príncipe João de Diogo de Teive. Introdução, texto, versão e notas. (Lisboa 2 1999) 27 sqq.; Luís de Sousa Rebelo, "Damião de Góis, Diogo de Teive e os arbitristas do século XVI", in Humanismo Português na época dos Descobrimentos cit., 204-216, maxime 206-210. Sobre a expansão portuguesa são notáveis os trabalhos de Luís de Matos, L'expansion portugaise dans la littérature latine de la Renaissance (Lisboa 1991); Idem, "L'expansion portugaise dans la littérature latine de la Renaissance", in L'Humanisme Portugais et l'Europe cit., 397 - 417.

33 Vide Nair de Nazaré Castro Soares, 0 príncipe ideal no século XVI e a obra de D. Jerónimo Osório cit., 192-197.

34 Vide 0 que se diz da maldade e intrepidez de carácter deste soberano, Mohamede, in Comentários de Afonso de Albuquerque, tomo II, p. Ill, cap. XVII, 92-93.

${ }^{33}$ Ibidem, 83: 0 reino de Malaca confína com o reino de Queda, o reino de Pam e 0 reino de Sião. Destes reinos, pelo menos o mais importante, 0 de Sião, era governado por um gentio. 0 rei D. Manuel, por saber «que elle era Gentio e não mouro, lhe tinha grande 
Nair de Nazaré Castro Soares

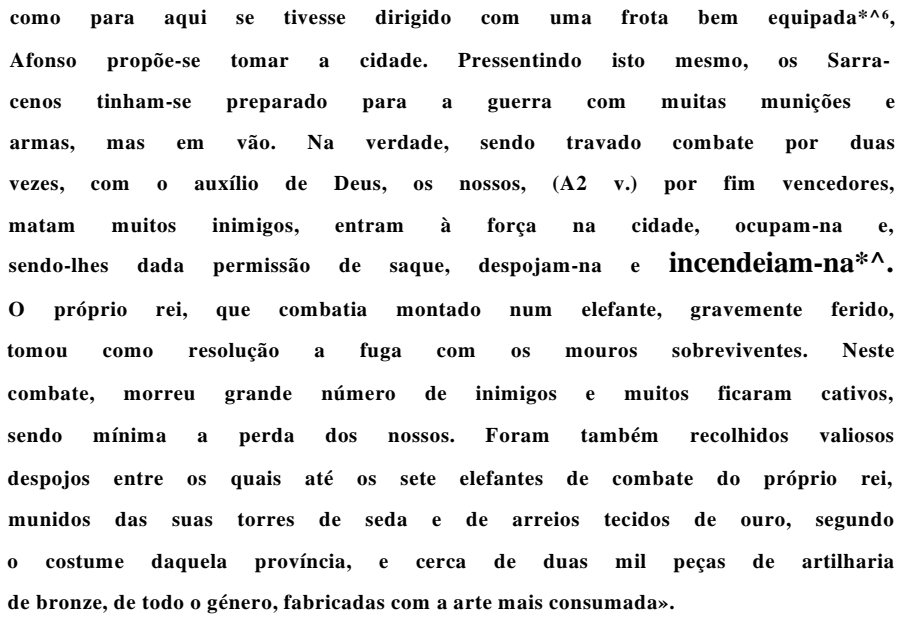

A construção de fortalezas que servissem de baluartes à insta lação dos portugueses em pontos estratégicos, onde fiscalizassem as actividades mercantis e observassem os movimentos dos chefes políticos e militares de todas as regiões orientais foi um dos objectivos prioritários na actuação de Albuquerque.

Se a acção do Governador se traduz numa visão mercantilista que pretendia firmar o monopólio do comércio das especiarias nas mãos da coroa portuguesa, a imagem da mesquita destruída, símbolo da religião dos infiéis derrotada, dava força e vigor espiritual à fortaleza que se erguia no seu lugar, com a bandeira das cinco quinas, as cinco chagas de Cristo.

A riqueza, os proventos comerciais, indispensáveis à perma nência e manutenção de homens, de barcos e de material bélico, nas para- * 3637

afeição e desejava de ter paz e amizade com elle». As gentios, por serem dedicados e leais aos portugueses, é-lhes dado maior crédito e favor do que aos mouros. Sobre os reinos desta regiâo, com mapas ilustrativos, vide o excelente estudo de Luís Filipe F. R. Thomaz, "0 malogrado estabelecimento oficial dos Portugueses em Sunda e a islamização da Java colectânea documental organizada, apresentada e anotada" $\rightarrow$ in Aquém e Além da Taprobana. Estudos Luso-Orientais à memória de Jean Aubin e Denys Lombard. Edição organizada por Luís Filipe F. R. Thomaz (Lisboa 2002) 381-607.

36 Compunham esta frota dezanove naus com mil e quatrocentos homens, oitocentos por tugueses e seiscentos malabares. Vide e. g. Góis, p. Ill, cap. XVII, 73.

37 Ibidem, cap. XIX, 84. Dizem os historiadores que os soldados vitoriosos põem fogo e saqueiam a cidade. Nas casas dos Malaios e Guzarates, achou-se tanta fazenda que se os nossos a soubessem guardar, cada um voltaria rico para suas casas. Todas as cronicas relatam a superioridade dos danos causados ao inimigo. 
gens longínquas de além-mar, eram a expressão da magnificentia, da grandeza e do poder de um rei que, nos quatro continentes, firmava o seu império e a sua Fé.

Damião de Góis, o moço-pajem de D. Manuel, com racionali dade, justificava os lucros como paga do esforço, do trabalho, dos muitos dinheiros despendidos em tão grande empresa ${ }^{38}$.

Assim prossegue o relato epistolar:

«Tomada assim a cidade $\mathrm{e}$ derrotados os inimigos, para proteger melhor as nossas forças, na foz do rio que atravessa a cidade, de onde poderia olhar melhor pela sua segurança, dado que a terra $e$ mar estão por todo o lado sob o seu alcance, construiu ele uma forta leza, bem provida de muros de quinze pés de largura, com pedra que naturalmente aproveitou dos templos arrasados dos Sarracenos, a que chamam mesquitas. Admirável, pois, a Providência divina, já que, onde por tanto tempo foi celebrado o culto da perfídia maometana, onde tantas vezes se blasfemou do nome do nosso Redentor, aí, por oculto desígnio de Deus, com grande (A3) louvor Seu e desonra de Satanás - objectivos que prosseguimos com tanto trabalho e sangue dos nossos, para aumento da fé católica - aí havíamos de receber ajuda para esta construção e obra tão necessária aos cristãos.»

De novo a insistência na actividade mercantil e a relação cir cunstanciada de povos das mais variadas regiões orientais que, pelo exo tismo de seus nomes e das terras de suas proveniências, representam uma visão alargada do mundo que os contactos dos portugueses favoreceram.

São eles, de livre vontade, sujeitos às leis, à justiça, à moeda dos portugueses - a lembrar os tempos modernos, no que se prende com a entrega de Macau à China.

A cunhagem da moeda em terras tão longínquas da coroa, por mão de Afonso de Albuquerque, é a prova inequívoca da independência na administração dos governadores, nas paragens longínquas onde se

38 Damião de Góis daria resposta, anos mais tarde, em nome da sua nação, ao mundo da humanitas, a Paulo Jóvio que apontava o dedo, tal como Erasmo, ao monopólio mercantil dos portugueses. Paulo Jóvio, num texto de 1525, inserto no Nouus orbis (Basileia 1532) de Simão Grineu ataca a política portuguesa das especiarias, os altos preços e a sua falta de qualidade. Damião de Góis contesta as afirmaçoes de Paulo Jóvio, no final dos seus Commentarii rerum gestarum in India 1538 citra Gangem (1539). Publica de novo esta sua contestação nos Opuscula (1544), com o titulo De rebus et imperio Lusitanorum ad Paulum Iouium Damiani Goes disceptatiuncula. Também Diogo Pires irá contestar a omissão de nomes ilustres dos portugueses, nos Elogia do Bispo italiano. 
estende o Império - reis, em nome do rei, como lhes chama D. Jerónimo Osório $^{39}$-, que servem o seu rei com lealdade, virtude inabalável na alma portuguesa, como sublinha Camões.

Este alargamento do poder através de alianças comerciais, que se traduz ainda na recepção das nossas instituições e costumes, numa per feita aculturação, é uma constante ao longo da carta ${ }^{40}$ :

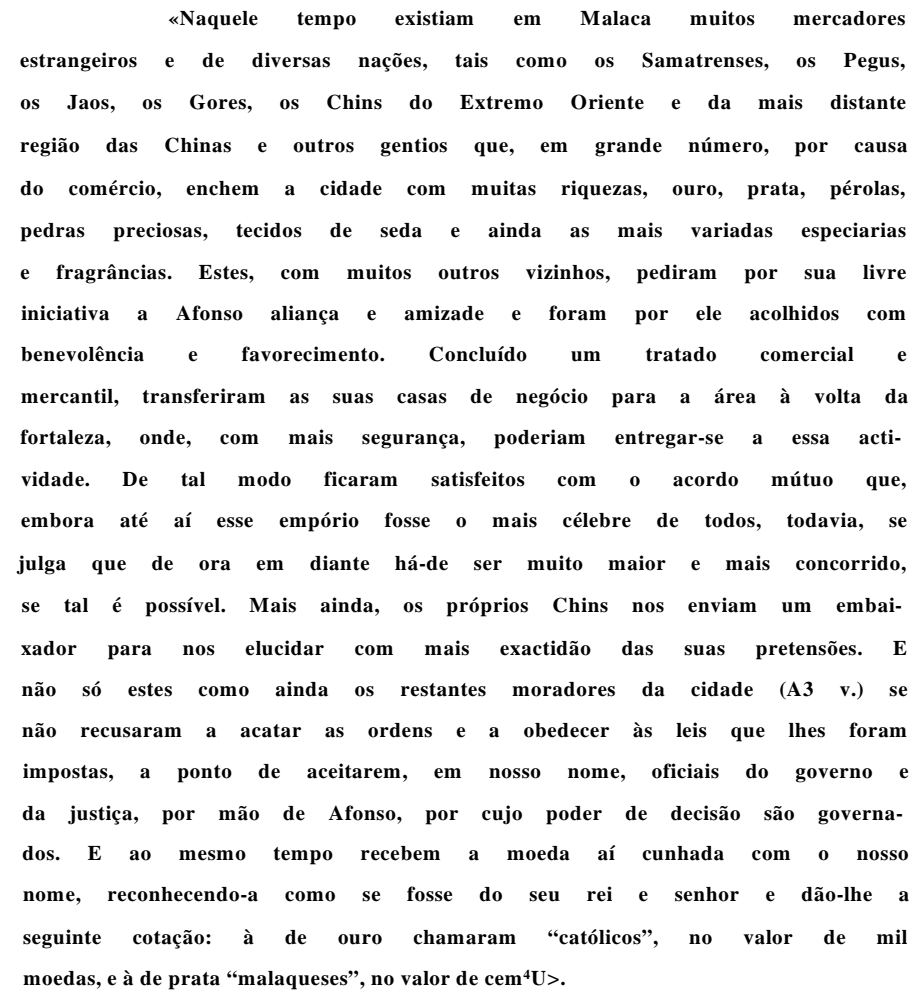

39 Vide Nair de Nazaré Castro Soares, 0 príncipe ideal no século XVI e a obra de D. Jerónimo cit., 397.

40 D. Manuel recomendava, em 1514, em carta a Rui de Araújo que se encontrava ao tempo em Malaca: "saibã que nosas gemtes nom soomente sã̃o conquistadores $\mathrm{e}$ ganhadores da terra que possuem os imigos de nosa santa fee catlica, mas que nos trautos e mercadorias gardam e fazem verdade». E acrescenta: «Paz e amisade com todos vos encomendamos»: Cartas de Afonso de Albuquerque, VII, 116-117.

$4 \wedge$ Afonso de Albuquerque «fez oficiais Gentios \& Mouros que lhe pareceram necessários, pera governarem os moradores daquela cidade, \& por que de todo se soubesse que estavã ha obediênçia del Rei de Portugal lhes deu regimento, \& ordenanças per õde se

Faculdade de Letras Universidade de Coimbra 
Significativa para a estratégia de Afonso de Albuquerque é a amizade do rei de Sião, que deu o maior acolhimento aos embaixadores de D. Manuel* ${ }^{* 2}$ :

O proselitismo religioso, a Evangelização, presentes nesta epístola, de par com os interesses comerciais a salvaguardar, resumem estas palavras:

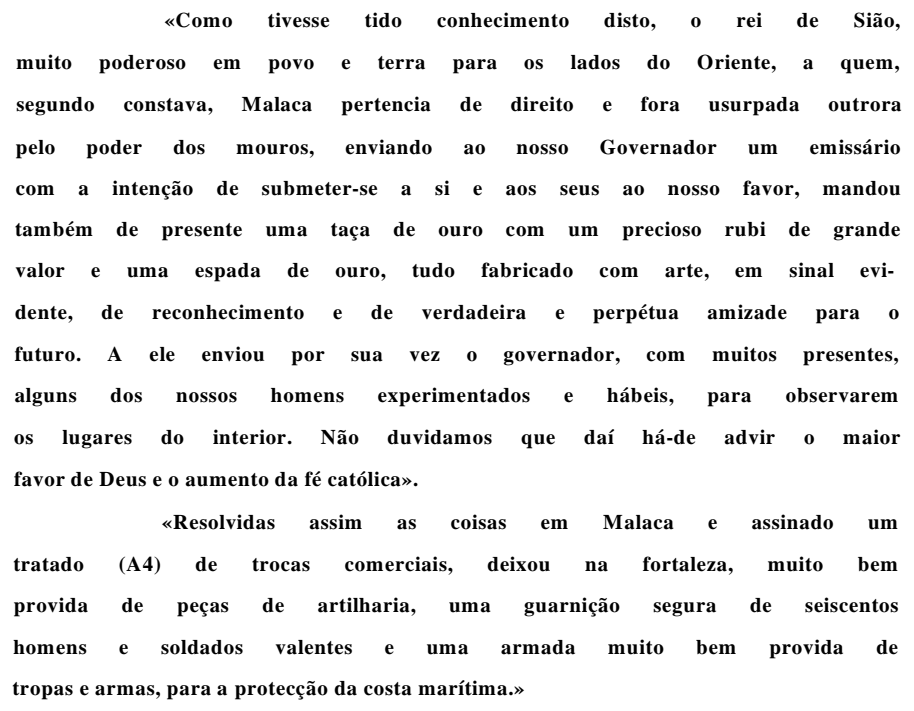

A bravura e a coragem, o espírito agónico, intrépido do Gover nador não conhecem tréguas. Desde 1505 a 1515 , ano da sua morte, ser viu a causa em que acreditou, «mais do que prometia a força humana». Prova-o esta atribulada viagem à índia, com a sua nau despedaçada pela intempérie, perdendo tesouros valiosos, despojos da conquista de Malaca.

A par de uma visão estratégica extraordinária, a rigidez de princípios de Afonso de Albuquerque, que não passou despercebida a Camões - que lhe chamou "Albuquerque terríbil" \{Lus. I. 14), mas tam bém Grande Capitão \{Lus. X. 45) — revela-se também no que se refere ao castigo exemplar infligido aos arrenegados. A atitude do Governador que

regessem \& fez moeda noua (cf. Góis, p. Ill, cap. XIX, p. 84-86). A valia das moedas difere, segundo os cronistas.

42 Vide também a embaixada do r
Comentários de Afonso de Albuquerque, $\mathrm{p}$. Ill, cap. XXXV.

Faculdade de Letras | Universidade de Coimbra 
esta carta, dirigida ao chefe supremo da Cristandade, não deixa de registar - embora desumana e cruel, dentro do espírito de tolerância e de respeito pelo homem, próprios do humanismo cristão - mostra claramente que, em história, não se podem fazer juízos críticos, partindo de concepções diversas das do tempo em causa.

Prossegue a carta:

«De regresso à índia, Afonso encontra cercada de mouros a principal fortaleza da cidade de Goa, que em anos anteriores, com grande perigo dos nossos, mas maior chacina dos inimigos ${ }^{4 . *}$, ele próprio submetera e acrescentara à nossa jurisdição e império. Tinha sido construída ao lado uma outra fortaleza muito sólida, de onde seis mil Rumes e Turcos constantemente acometiam os nossos ${ }^{*}{ }^{44}$. 0 governador atacou-os e depois da morte de muitos, desesperando já da salvação, entregaram-se finalmente a si e aos seus bens, apenas com a condição de salvarem a vida. Ai se conseguiram também despojos não despiciendos de máquinas, cavalos e armas. E, enfim, sujeitos ao devido suplício alguns apóstatas que se encontravam entre os mouros e que tinham abandonado a nossa fé, restituiu à cidade a antiga calma» ${ }^{45}$.

A carta refere, em seguida, a embaixada que a corte etíope, o reino do Preste João, enviou a Goa, onde teve uma magnífica recepção de Afonso de Albuquerque, que logo tratou da sua partida para Lisboa, onde

${ }^{4 \wedge}$ vide Comentários de Afonso de Albuquerque, tomo II, p. III, cap. Ill, 16-18.

44 Enquanto Afonso de Albuquerque permaneceu em Malaca, Goa era atacada $e$ quase soçobrava às forças dos soldados de Sabaim Dalcão. Além disso, a fome consumia os nossos, pois «Sabaim Dalcão tinha os passos todos da ilha tomados porque nenhum comestível atravessasse da terra firme a Goa» (Osório, vol. II, liv. VIII, p. 58-59). No entanto, a coragem deles fe-los aguentar até à chegada de Afonso de Albuquerque que, com a melhor táctica, combateu e levou de vencida os mouros de Benastarim \{Cartas de Afonso de Albuquerque, tomo I, carta XII de 23 de Novembro de 1512). Todos os historiadores narram estes sucessos.

\footnotetext{
45 Tendo Roçalcão perdido a esperança de poder defender a cidade, pediu tréguas a Afonso de Albuquerque, tendo concordado em entregar-lhe os cristãos arrenegados, uns setenta - que, não suportando a fome, se passaram de noite para o lado inimigo (segundo Jerónimo Osório, vol. II, liv. VIII, p. 59) - , com a condição de lhes ser poupada a vida. o comandante português cumpriu a promessa, mas não os poupou ao suplício. Os Comentários de Afonso de Albuquerque (p. Ill, cap. LI, 262) narram o seguinte: «Afonso Dalboquerque como não havia de faltar de sua verdade, guardou-lhes o seguro quanto á vida, como tinha prometido a Roçalcão, e mandou-lhes cortar a todos a mão direita, e o dedo polegar da esquerda, e as orelhas, e narizes, por memoria, e espanto da treição, e maldade, que cometeram contra Deos, e seu Rey». Todos os historiadores repetem estes factos.
}

Faculdade de Letras i Universidade de Coimbra 
aportara em 151446. A grandiosa e solene recepção do embaixador Mateus, na capital do império, e o que ela representa no imaginário nacional, deixara marcas indeléveis na literatura do tempo ${ }^{47}$.

A ajuda do Preste João, com o seu poder mítico, era esperada no dominio do espiritual e do temporal - e gigantesca! - designadamente na conquista de Adem, a entrada do Mar Vermelho, objectivo que Albu querque, com a sua morte, deixara por cumprir.

É este o relato da carta:

«Entretanto, aportara à cidade de Dabul, não longe de Goa, um enviado ao nosso governador de um poderosíssimo senhor da Cristandade, Preste João, para, em seu nome, isto é, como de cristão a cristão, espontaneamente oferecer toda a riqueza (A4 v.) e tudo 0 que fosse necessário para a guerra contra os inimigos da fé católica, exércitos de soldados, aprovisionamentos de armas e socorros, principalmente se a nossa armada viesse a atravessar 0 mar Vermelho, que fica junto dos seus domínios. Aí muito comodamente as forças de ambos poderiam reunir-se. Envia-nos não pequeno lenho da adorada e verdadeira Cruz e pede homens hábeis e abalizados, por cujo engenho e conhecimentos técnicos julga possível modificar por qualquer modo 0 cur so do Nilo, desviando-0 do território e região do Sultã $0^{4 * *}$.»

46 O legendário reino de Preste João desde o século XII atrai a imaginação da Europa, no seu afã cruzadístico. Os portugueses buscam-no desde o Século XV, desde os descobrimentos empreendidos pelo Infante D. Henrique;. D. Manuel alimentara, desde longa data, o sonho de vir a libertar Jerusalém, com a sua ajuda, do domínio do Infiel. Este espírito de cruzada, e mesmo de messianismo manuelino, sempre com os olhos postos no grande rei cristão do Oriente, animara de sobremaneira a viagem de Vasco da Gama à índia. Sobre a aura mítica do Preste João e as relações Portugal-Etiópia, vide Luís de Matos, "L'expansion portugaise dans la littérature latine de la Renaissance", in L'Humanisme Portugais et l'Europe cit., 414-416; Luís Filipe R. Thomaz, 'L'idée impériale manuéline', in La découverte, le Portugal et l'Europe (Actes de Colloque, Paris - Mai 1990), (Paris - F. c. Gulbenkian 1990) 35-103, maxime 60.

47 Marcou profundamente o jovem Damião de Góis, cujas obras são documento. cf. Damianus a Goes Lusitanus, Legatio Magni Indorum Imperatoris Presbyteri Ioannis ad Emmanuelem Lusitaniae Regem, Anno Domini M. D. XIII. [Cólofon] loan. Grapheus typis excudebat Anno M. D. XXXII. mense Septemb. [Antuerpiae]; e ainda a obra sobre a crença dos abexins, que descreve em pormenor as relações luso-etíopes e as conversações mantidas com Zagazabo, que veio na embaixada do reino de Preste João de 1527: Damianus a Goes Lusitanus, Fides, religio moresque Aethiopum sub imperio Pretiosi Ioannis [...]. Louanii, ex officina Rutgeri Rescij, An. M. D. XL.

$4 \wedge$ Desviar o Nilo seria o maior agravo que se poderia fazer ao Sultão do Egipto, o que por vezes acontecia, sendo disso responsáveis certos povos vizinhos. Vide Cartas de 
Pondo agora em relevo as alianças $\mathrm{e}$ as amizades dos reis $\mathrm{e}$ príncipes, atraídos pela fama dos feitos dos portugueses e pela grandeza do seu rei, a epístola acentua a Gloria, a Honor, a Magnificentia, a Dignitas - as rodas do Carro Triunfal de Maximiliano, de Dürer indispensáveis ao nome de rei do Renascimento* ${ }^{49}$.

São estes os termos:

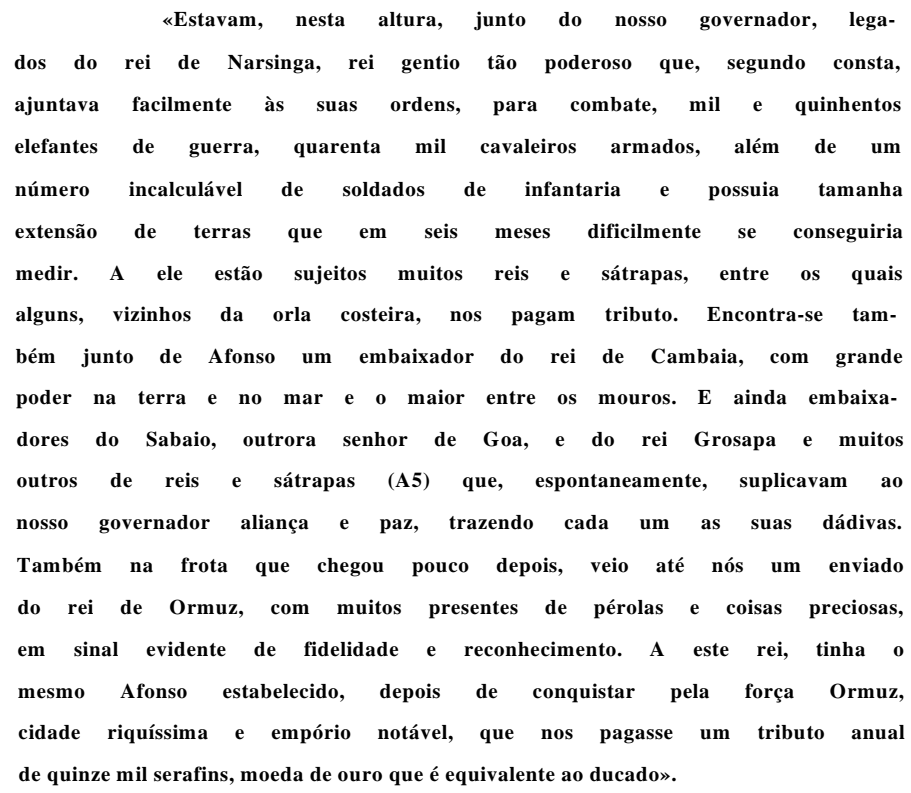

Termina a carta por uma espécie de peroratio. É neste final que o latinista que a redigiu ${ }^{50}$ exprime em poucas palavras o essencial da

Afonso de Albuquerque, tomo 1, carta XLI (4 de Dezembro de 1513). Se tal realizassem, fragilizariam as forças que se opunham à conquista de Adem.

49 Vide Nair de Nazaré Castro Soares, 0 príncipe ideal no século XVI e a obra de D. Jerónimo Osório cit., 192-197, 274 sqq.

50 Havia bons latinistas neste tempo em Portugal, como 0 refere o Prologus de Estêvão Cavaleiro à sua Noua grammatices marie matris dei virginis ars de 1516 (vide Américo da Costa Ramalho, «Um capítulo da história do Humanismo em Portugal: 0 Prologus de Estêvão Cavaleiro», in Estudos sobre o séc. XVI (Lisboa21983) 124-152. Entre esses latinistas, figuram Diogo Pacheco, Luís Teixeira, Francisco Cardoso, Cataldo, então no fim da vida, e 0 próprio Estêvão Cavaleiro. Qualquer deles poderia ter sido 0 autor do texto latino desta carta. 


\section{A Carta de D. Manuel ao Papa Leão X}

matéria tratada, conferindo ao discurso veemência e espiritualidade capa zes de docere, mouere et delectare o seu destinatário privilegiado e um auditório mais vasto - o Papa Leão $X$ e a Cúria romana, palco do mundo.

Apresenta-se o tema conceptualmente mais rico e que foi ver dadeiro leitmotiv: a fides amplianda, a dilatação da fé, a Evangelização; e a promessa de vitórias futuras das gentes e do rei de Portugal, unidos às forças do Preste João, sob a bandeira da Cruz. Há como que um canto ao advento de uma nova respublica Christiana, sob a égide do Sumo Pontí fice, representante de Deus na terra, a quem se presta obediência, se quer felicitar e agradecer:

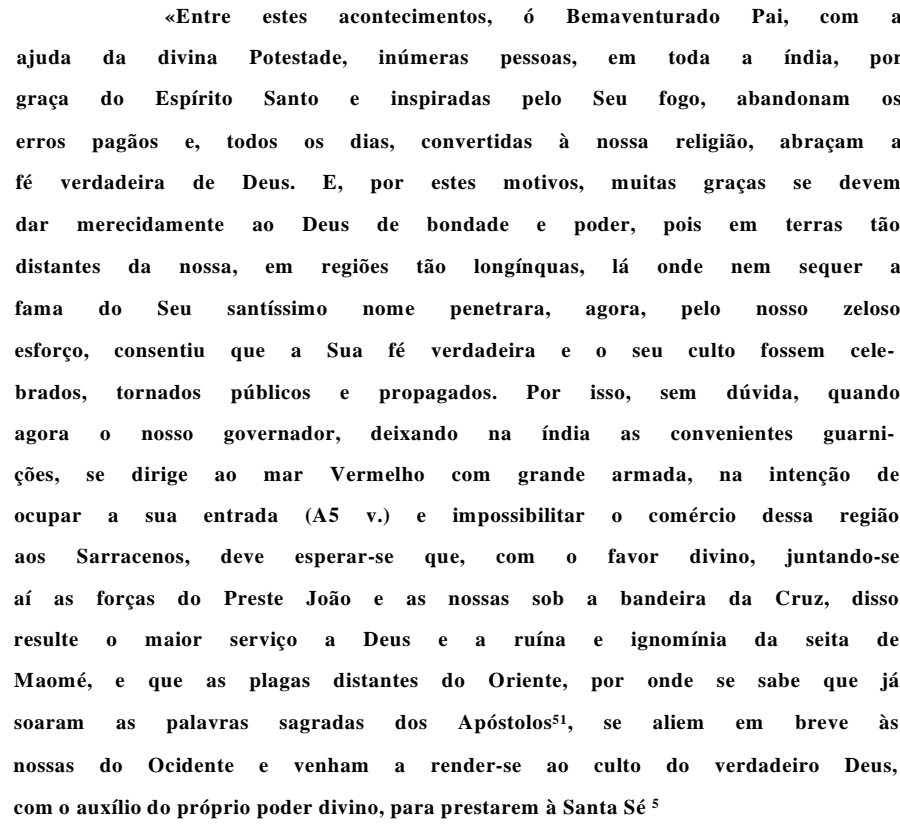

5 Em Goa, quando se construía a fortificação da cidade, depois de ser tomada a Hidalcão «andando certos homens desfazendo humas paredes velhas, pera tirarem pedra pera a obra, acháram nos alicerces huma Imagem do Crucifixo de cobre. Como a nova correo por toda a cidade, veio Afonso Dalboquerque logo ali ter com toda a gente, e Clérigos, e muitas lagrimas á Igreja, foi grande espanto este pera todos os que viram, porque não havia memoria de homens, que se lembrassem que houvera ali nunca Christãos (Vide Comentários de Afonso de Albuquerque, tomo II, p. Ill, cap. IV, 21-22). Camões, Os Lusíadas, canto $\mathrm{X}$, 108-118, refere-se também, seguindo uma tradição muito antiga, e provavelmente verdadeira, à presença de $\mathrm{S}$. Tomé na índia. 
Apostólica e a Vossa Santidade, como excelentre pastor do rebanho cristão, a homenagem e a obediência que, por costume, the são devidas.

A saúde de Vossa Santidade, a quem Deus todo piedoso se digne conservar e engrandecer, conforme os Vossos desejos, por muito tempo e na maior felicidade.

Dada em a nossa cidade de Lisboa, aos oito dias dos Idos de Junho do ano de $1513^{52}$.

Impressa em Roma por Diogo Mazochio, a 9 de Agosto».

Podemos concluir que esta carta apresenta, nitidamente deli neados, os objectivos político-estratégicos, económicos e religiosos de Afonso de Albuquerque -, o seu projecto grandioso para a sua empresa no Oriente. O muito que se cumpriu e o que ainda se sonha realizar ${ }^{53}$.

Mais precisamente, é este "Grande Capitão", com as suas vir tudes guerreiras e vitórias militares, a expressão animada da potentia do rei português, senhor de um imperium.

É que as epistulae e orationes latinas, destinadas à propaganda internacional têm uma unidade temática e formal, centrada na laudatio principis como imperator, como rex inuictissimus ${ }^{54}$.

Neste sentido, a carta de 1513 antecipa e prepara, no género epistolar, a oração de obediência proferida pelo jurisconsulto Diogo Pacheco, em nome de D. Manuel, ao papa Leão X (1514), que trata os mesmos temas, com admirável ênfase retórica e cor poética, merecendo rasgados encomios, em verso, de humanistas da época.

Prova disso é o poema de Camilo Pórcio que, ao elogiar o ora dor e o seu monarca, tem na memoria a celebração do ano anterior, em Roma, por ocasião do recebimento da carta que dá a noticia, em primeira

52 O mesmo será dizer, 6 de Junho de 1513.

53 Esse plano visava impor o imperialismo portugués a toda a área do oceano índico, com uma fiscalização apertada das suas múltiplas linhas de navegação, apoiada pela construção de fortalezas em terra, em lugares estratégicos: Ormuz, que controlaria o golfo Pérsico, Diu a região de Cambaia, Adem a entrada do Mar Vermelho; Malaca, pela situação geográfica privilegiada, era o porto ideal par o encontro do comércio do índico com o Pacífico. Além disso, era um apoio insubstituível à expansão portuguesa pelo Oriente: nela se realizavam as copiosas trocas de mercadorias, que afluíam ao porto; dela partiam os navios de exploração das ilhas Indonésias, das Molucas, da China e do Japão. Vide Luís de Albuquerque, Os Descobrimentos Portugueses (Lisboa 1985) 184.

s^ Vide Luís de Matos, L'expansion portugaise dans la littérature latine de la Renaissance cit., 160-161; J. A. Osório, "Os primeiros textos em latim de propaganda da expansão portuguesa. Séculos xv-xvi", in Congresso Internacional Bartolomeu Dias e a sua época - Actas, vol. IV (Porto 1989) 533-545.

Faculdade de Letras i Universidade de Coimbra 
mão, das façanhas dos Portugueses no Oriente. Estes versos são assim a tradução poética da mensagem por ele transmitida, com a mesma emoção, no seu discurso de 1513:

«Já antes, ó Manuel, Rei dos Reis, passara para ti

A glória das armas e da guerra; já antes nos

arrebataste o louvor e brilho da milícia, com que outrora

A grande Roma, mãe dos deuses e dos homens,

Se elevou até ao céu. Isto, porque, banindo as guerras

Civis que atormentavam a mísera Europa,

Voltas feliz as armas contra os inimigos infiéis,

Feres os Indos, os Etíopes e os reinos ignotos que recorrem à guerra,

E domas com inúmeras armadas o mar indignado.» ${ }^{55}$.

Numa palavra, a epístola latina de D. Manuel a Leão X narra, com um sensacionalismo quase jornalístico, a gesta lusa, o seu alcance temporal e espiritual, revelando-se a expressão acabada da retórica do poder, da propaganda e da glorificação épica, no período áureo da nossa história da expansão ultramarina ${ }^{56}$.

55 Vide poemas em apêndice, que servem de testimonia à "Oração do jurisconsulto Diogo Pacheco, dita na prestação de obediência em nome de Manuel, Invictissimo rei de Portugal, ao excelente Sumo Pontífice Leão $\mathrm{X}$, in Orações de obediência, séculos XV $a$ XVII cit, vol. 6, 32 .

56 Se se pode duvidar de um verdadeiro Império Português do Oriente, apesar dos promissores resultados alcançados nos primeiros quinze anos do século XVI (Luís de Albuquerque, Os Descobrimentos Portugueses cit., 192), é inegável o sonho que comandou a vida de um povo, que deu ao mundo novos mundos, e que, com a viagem do Gama à índia, abriu as portas da época moderna. 
Nair de Nazaré Castro Soares

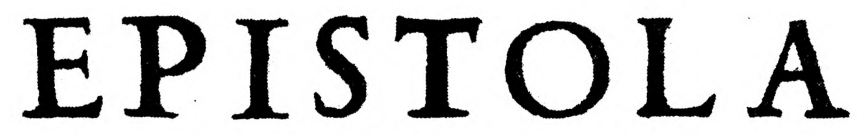

Potentiffrmi/ac inuietiffrmi Ema/

nuelis Regis Portugalix \& Algarbiorum.

Qc. De Vietoriis habitis in India

\& Malacha. Ad +S, in Chrifto Patrem \&

Dr̆m noftrum Dr̈m Leonem . $X$.

Pont, Maximum .
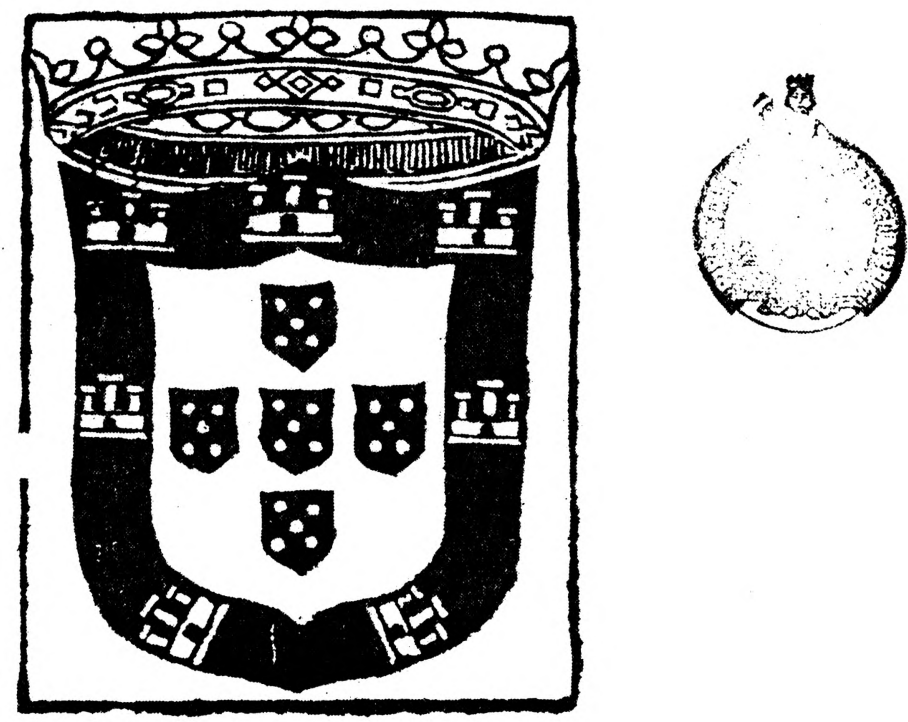
Anctiffimo in Chrifto Patri/ac bea I tiffimo Dño Dño noltro E.S. ad/ ditiffimus filius Emanuel Dci gra tia Rex Portugallix \& Algarbioge cirm ultraq mare in Affrica Dominus gui nę̧ \& conquiftę nauigationis/ac cómertii Ethiopix/Arabię/Perfix/ato/Indix/humil lima beatorum pedum ofcula . Quantum Deo Opt. Max. ğtum \& tibi gratulari del beamus Beatiffime Pater/uel ex nuntio qd' noftra Indica Claflis proxime attulit fatis apparet, Quod enim te Pont. Max.te.S. Ro.Ecclefix \& Chriftiano Orbi prefiden te tam admiranda in Dei laudem ac gloriá gefta tam ex uoto fuccefferint tua certe laus tua gloria cenferi debet, Iure itaqu uifum eft quę in India Dei fuffragio ad ipfius cultum fpectantia noftris armis modo facta fint ad tuam Sanctitatem/utpote totius Chriftiang Reipublicę Caput \& orthodoxe religionis normam/ carptim ac fummatim/ne ftilum Epiftolarum excedamus prefcribere/utpro rerum dignitate cuncta penfari / fummogs deo accepta referri ualeant/ac indies fui fan etiflımi nominis glifcentem laudé $x$ ṕianiq

$A$ ii 
dogmatis propagationem facile fperemus . Igirur paccata poft plures dubii Martis ui ctorias non fine labore \& fanguine partas I India relictis in ea opportunis prefidiis $\mathrm{Al}$ phonfus de Albiecherq 3 protho capitaneus nofter ut lacturä/quä fuperioribus annis nrỉi feceranc/iniuriàq ulcifceretur auream $C h e r$ fonefum/Malacham accole appellant con/ tendit/ea cif inter finum magnum $\&$ Gange iicum lita $V$ rbs mire magnitudinis/ utg ui

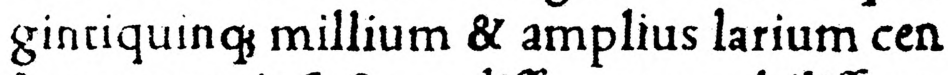
featur terra ipfa fecundiffima/ac nobiliffima rum/quas fert India mertium feraciffima ce lebratufimum ob id Emporium/ubinon modo uaria aromata \& omnigeni odores/ fed Auri quog/Argenti/ Margaritarum ac precioforum lapillorum magna copia af/ fluit : Hanc Rex Maurus gubernabat ea/ tenus uires fuas Maumetica Secta proten/ dente/ catera Gentiles tenent : Huc itag cum inftructa Claffe applicuiffet Alphon' fus V rbem oppugnare deftinat: Quod pre fentientes Sarraceni bello/fe multis Mu/ nitionibus / \& Armis præparauerant/fed fruftra : nam commiffo bis pralio/noftri 
randem Dei auxilio fuperiores plurimis ex hoftibus cefis urbem ui intrantfoccupät da ta prede libertate dirripiunt/incendút. $\mathrm{R}$ ex ipie qui ex Elephàto pugnabar grauiter uul nerarus cum iuperftitibus maurs fuga $\mathrm{fbi}$ confuluit/ı ea pugna magnus hoftum nu merus exiguo noftrorum damno enteriit $\mathrm{ca}$ pri plures/magna etram ablata fpolia in qui bus \& feprem ipfius $R$ egis bello affueti Ele phantes iuis curribus fericis atq auro intex tis Ephippiis illius Prouintize morc muditi ac ęneorum omnís generis tormentorú ad duo millia fumma arte fabricata. Capta fic urbe hoftibufs proftigatis quo noftra rei tutius confuleretur in fiuminis quod medi/ am urbe incerfluit holtio unde terra mariqs fubacto undig fux fecuritati profpitiar $m u$ nitiffimam arcem murorun quindecim pe dum laticudine conftruxit/ex lapide uideli/ cet qui ex dirutis Sarracenogz quas Meiqui tas uocant edibus excerptus eft. Mirabilis profecto druina prouidentia/quod ubi táto tempore Maumetice períldix cultus celel brarus/ubi redemptoris noftri nomé toties blafphematum inde occulto dei cóflio ma

$A$ iil 
gna fua laude ac fathane dedecore/ ğ táto la bore ac noltrope fanguine tandiu p catholil cx fidei augumento affectamus . Huic edil ficio $\&$ xp̈ianis tam neceffario operi opem acceperimus : Erant co tempore Malache plures extranei ac diuerfarum nationú mer catores/fcilicet/Zamatri/Pegus/Iaäes/Col res/ $\&$ ab extremo oriente atg ultima Sinal rum regione Chines/aliig Gentiles/ qui ur bem comertii gratia frequentes multis diui tiis auro/argento/margaritis/ \& pretiofis $\mathrm{I}_{2}$ pillis ferico etiam uellere/ac multifariis aro matibus $\&$ odoribus affatim replent hii $c \bar{u}$ multis quo o finitimis ab Alfonfo fędus $\&$ amicitiam ultro flagitantes ab ipfo / \& beni gne \& fauorabilicer funt accepti/pacto qu có mertii $\&$ mercaturę tractatu fuas negotiatio nis domos circum arcem ubi tutius uerfari poffent fecum träftulere mutuo fędere adeo İcri/ut g̈uis hactenus illud emporium om/ nium füerit celeberrimü/deinceps tamen/fi fieri poterit multo maius ac celebrius futu/ úr exiltimetur a quin \& ipfí Chines nuntiú ad nos mittunt /a quo perfectius res fuas in telligamus.Atq̧ adeo tam hü ö cęteri urbis 
a ccole dicto audire imperatifo legibus pal rere non recufarunt ut $R$ eip. regiminis iu/ ftitięq officiales noftro nomine Alfonfi ma nu acceperint/ quope iuditio $\&$ arbitrio gu/ bernantur fimul $/ 8$ monetam noftro ibi no mine cufam tang̈ $\mathbf{R}$ egis dominiqg fui agno fcentes excipiunt/ $\&$ expendunt auream cal tholicos mille fcilicet númorum argenteam centũ ualore Malachenfes infcripfere : Hęc cum cognouiftet $R$ ex de Anfiam \& gente $\&$ folo Orientem uerfus potentiffimus/ad quem fama erat iure Malacham fpectare $\&$ a Mauris olim ufurpatam legato ad Prefe' Ctum noftrum deftinato/qui fe fuo manciparet obfequio/auream fimul craterć cú pretiofo mágneq̧ exiltimationis carbun culo enfeq, auro ad fabre elaboratum in fig num uidelicet recognitionis ac uere perpel tueg futurę amicitię dono mifit/ad qué pre fectus aliquos /e/ noftris expertos uafrofq uiros intima regionis fcrutaturos cum mul tis etiă muneribus remifit/ unde maximum dei oblequium \& catholicx fides augumen tum fore non dubitamus. $\mathbf{R}$ ebus fic apud Malacham compofitis \& obfirmato tracta 
tus cómertii fędere relıcto in arce tormentls machinif $q_{3}$ munitiffima fexcentoge etian ui rorum ac ftrenuoßz militú fecuro pręfidio \& claffe ad marıtime ore tutelam uiris ai mifqs optime inftructa, Alfonfus in Indiam reuer tens Goe urbis pręcipuá arcé quá iple fupe rioribus annis magno noftrope periculo fed maiore hoftiú ftrage occupauerat noftrę̧ ditioni $\&$ imperio adiun xerat a Mauris ob= feffam reperit / extructa etiam iuxta alia fir/ miffima arce/unde $R$ uminú Turcho qua fex millia noftros cótinue infertabant/quos cí adoriretur prefectus plurimis iam truci/ datis defperata falute pacta tantúmodo cor porum incolumitate $f_{e}$ tandem ac reliqua noftris dedidere partifqg $\&$ ibi machinarum equorum armorum $\&$ huiufmodi haud có temnendis fpoliis quibufdam etiam qui in/ ter Mauros reperti funt apoftatis qui a fide noftra defciuerant debito afflictis fupplitio urbem priftine quietı reftituit. Appulerat interea Dabuli urbi haud pcul a Goa pres byteri Ioannis potentiffimi chrifticolarum dñi ad prefectum noftrú legatus qui cius no mine ut Chriftiani Chriftiano oem opem 
o mnia ad l illum contra catholicæ fidei hò ftes opportunasmilitum exercitus:arrnog. ac cómeatus prafidia ultro offerat:præfer 1 tim fi mare rubrum fuo coniunctum domi nio ứa claffis traiiciat: ubi cömodiffime utriufqg uries iungi poflent . Haud exiguú adorande $\&$ uere crucis lignum ad nos mit tit uiros uafros $\&$ induftrios pofcens quo $\&$ ingenio 8 artificio a Sulcani territorio $\&$ Regione Nilú.deflecti aliqua diuerti poffe exiftimat : aderant tunc apud noltrú prefel Ctum a Narfingue Rege legati/Rege Genti li adeo potentiffimo/ut mille \& quingentos belligeros Elephantes armatope equitú qua draginta millia pratex innumerũ peditú nu merum fuo arbitrio in aciem paruo negotic proferre tantū g̣tú femeftri itinere uix emettiri polfit / huic plures Reges ac Satrapes parent / quope nó nulli maritimis oris proximi nobis func tri butarii. Apud Alfonfum \& Cambaye $\mathrm{R}_{\text {el }}$ gis legatus/terra mariqs potentiflimi/atq in ter Mauros maximi . Item a Zabayo Goe quondam dño/atq a R ege Grofapa/Aliiq complures $\mathbf{R}$ egum Satrapumqlegati a no 
Atro prefecto fędus pacem qu ultro exorantes ac fua munera finguli afferentes, in hac etiá qux proxime appulit claffe ab Armufin $\mathrm{Re}$ ge legatus cum multis margaritape rerum q pretiofarum donis/in fignum uidelicet fide Iitatis \& recogntionis ad nos uenit : Hunc Regem Alfonfus idem urbe oppulériflima \& ṕpipuo emporio Armufio ui capto quin decim millium Seraphinorum/ea eft aurea moneta ducatis equiualens/annuum nobis tributariun effecerat. Inter hos fucceffus Pater Beatiffime Diuino fuffragante numi/ ne per uniuerfam Indiam plurimi Spiritus fancti gratia igneq, afflati depofitis gêtrilitiis erroribus indies ad noftram religionem có uerfi ueram dei fidem agnofcunt/obq Deo Opt. Max. fummx gratix funt merito refe rendx:quod tam procul a noftro orbe / in tam remotis regionibus/quo ne fama quidé fui fanctiflimi nominis penetrauerat/ noftra nunc fedula opera/ fuam ueram fidem cul

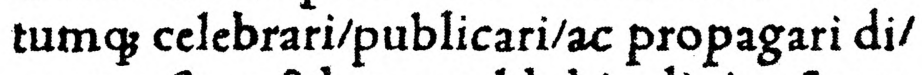
gnatus fit : ufide proculdubio diuina fauen te clementia fperandú eft/cum nunc Prefel etus nofter ad mare rubrū uc eius oftio ocl 
cupato Sarracents eape partiú cómcrtia in/ terdicat relictis in India oportunis prefidiis ingenti claffe properat ut ibi coniunctis fub Crucis uexillo pref byteri Ioannis noftrif ${ }_{3}$ uirıbus maximum dei obfequium/ $/ \mathrm{Mau}$ metice fecté detrimentum \& ignominia $\mathrm{fel}$ quatur/ extremaq Orientis ora/quo \& fa/ cras Apoltolope uoces /intonuiffe comper/ tum eft occidentali noftrz propediem iun/ gatur/ $\&$ ad ueri dei cultum ipfius fuffragan te numine rraducatur. S. Sedi Apoftolica ac tux fanctitati ut optimo paftori Chriftia ni gregis more debitum obfequium \& obe dientiam oblatura. Bene ualeat Beatitudo tua/quam pientiffrmus Deus diu ac fęlicifł fime conferuare $\&$ augere ad uotum digne/ tur. Dat, in Vrbe noltra Olifipone, 8 ,idus Iunias Anno Dŕi. M.D.XIII.

Romx impreffa per Iacobum Mazochium+9, Augufti.

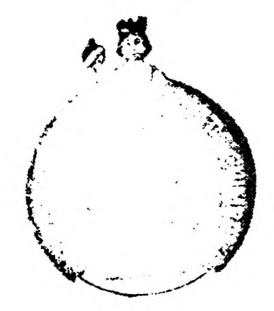

